\title{
MUC20 Gene
}

National Cancer Institute

\section{Source}

National Cancer Institute. MUC20 Gene. NCI Thesaurus. Code C153087.

This gene is involved in regulation of hepatocyte growth factor (HGF)/HGF receptor (cMet) signaling. 